\title{
FATE, DISSIPATION AND ENVIRONMENTAL EFFECTS OF PESTICIDES IN SOUTHERN FORESTS: A REVIEW OF A DECADE OF RESEARCH PROGRESS
}

\author{
Daniel G. Neary*†, Parshall B. Bush $\ddagger$ and ERRy L. Michael $\S$ \\ †USDA Forest Service and Soil Science Department, 2171 McCarty Hall, \\ University of Florida, Gainesville, Florida 32611 \\ ‡Extension Pesticide Residue Laboratory, Riverbend Research Laboratory, \\ University of Georgia, Athens, Georgia 30602 \\ \$USDA Forest Service, G.W. Andrews Forestry Sciences Laboratory, \\ Devall Drive, Auburn University, Alabama 36849
}

(Received 14 May 1991; Accepted 18 June 1992)

\begin{abstract}
Ten years of watershed-scale research has been conducted on the fate of forestry-use pesticides in forested catchments under mainly operational conditions throughout the southern United States. Studies have evaluated chemicals such as hexazinone, picloram, sulfometuron methyl, metsulfuron methyl, azin phosmethyl, triclopyr, carbofuran, lindane, malathion, fenvalerate, copperchromium-arsenic, and pentachlorophenol. Off-site movement in stream flow, leaching to ground water, and thermal combustion have been examined. Model verifications of pesticide fate and dissipation and risk analyses have been conducted using simulation models such as GLEAMS, CREAMS, and PRZM. Field study data indicate that movement is controlled by the main hydrologic pathways (e.g., surface runoff, infiltration, interflow, and leaching below the root zone). Peak residue concentrations tend to be low $(<500 \mu \mathrm{g} / \mathrm{L})$, except where direct applications are made to perennial streams or to ephemeral channels, and where buffer strips are not used and do not persist for extended periods of time. Indirect effects noted from the use of pesticides in forested watersheds include temporarily increased nitrate nitrogen losses, reduced sediment yields, temporal changes in terrestrial invertebrate abundance, reduced plant diversity, and changes in particulate organic matter transport in streams. Very limited cumulative effects research has been conducted. The effects of increasing watershed sire on herbicide concentrations and the impact of nonforestry pesticides on fish have been examined. Analyses conducted in regional environmental impact statements indicate that the low concentrations and short persistence of forestry pesticides in surface and ground water do not pose a significant risk to water quality, aquatic biota, or human health.
\end{abstract}

Keywords-Pesticides Forestry Water quality Environmental fate Indirect effects

\section{INTRODUCTION}

The southern yellow pine and hardwood forests of the South constitute one of the most intensively managed forest ecosystems in the world [1,2]. These forests occur within one of the fastest growing regional populations in the United States. Future resource demands in the South will certainly continue to intensify as the population expands and the forest land base shrinks. The whole mix of public and private forest resources, including wood, wildlife, recreation, range, and water, will need intensive management to meet increased demands. One

'To whom correspondence may be addressed.

Presented at the Symposium on Pesticides in Forest Management, I 1th Annual Meeting of the Society of Environmental Toxicology and Chemistry, Arlington, VA, November $11-15,1990$. crucial concern over this intensification of forest management is the potential effect of silvicultural practices on water resources and aquatic ecosystems.

Intensive forest vegetation management practices such as short rotations, clear-cut harvesting, mechanical site preparation, burning, drainage, and fertilization created concerns in the early 1970 s over possible adverse impacts to soil and water resources. Researchover the past twodecades has demonstrated the range of environmental effects of these practices $[3,4]$. If properly prescribed, applied, and guided, these practices can be conducted while conserving and protecting valuable soil and water resources.

In the past five to IO years, a further intensification of forestry has involved increased use of pesticides. These chemicals are now being used extensively across the managed forests of the region to produce genetically improved seed, improve the 
quality and vigor of nursery seedlings, reduce weed competition, minimize the use of soil-disturbing mechanical site preparation techniques, and increase tree growth. The driving force behind increased pesticide use has been the need to improve growth on a diminishing forestry land base at a lower initial investment cost.

The use of pesticides in the South is not new since agriculture has had a long history of pesticide applications. However, pesticide use in forest management has increased precisely at a time when states within the region have had heightened awareness of potential and actual water resource pollution problems due to agricultural pesticides. Thus, the coincident increased use of pesticides for silviculture, on forests which provide much of the South's streamflow source areas and groundwater aquifer recharge zones, has raised questions among the general public and resource managers alike.

Ten years ago, pesticide use was limited mainly to insecticide and fungicide applications in the small number of forestry nurseries and seed orchards. Insecticides were applied on a larger scale only to deal with sporadic outbreaks of pests like the southern pine beetle [5]. Herbicide use was very scattered and mainly in a testing mode. Now herbicides are a widespread vegetation management tool, and nearly all public and private forestry organizations have operational programs in suitable stands. A decade ago, very little information was available on the direct effects of forestry pesticides on water quality and aquatic ecosystems in the southern United States, much less the indirect ones [6,7]. Much of the scientific information on the environmental fate of forestry pesticides available in the late 1970s and early 1980s came from research done in the Pacific Northwest [8].

A decade later, considerable research has been conducted on the fate of pesticides used in forest ecosystems of the southern United States. Although many questions still remain and much research is still in progress, the beginning of the 1990s is an appropriate point to examine the progress of the past decade. The objective of this paper is to present a review of the progress achieved by research conducted during the late 1970s and 1980s on the environmental effects of pesticides in forest ecosystems in the South.

\section{Ecosystem fate}

When pesticides are applied to forest ecosystems, a number of processes affect the fate and effects of these chemicals. Understanding these processes is important to determining the environmental im- pact. The important zones and processes involved in pesticide application, movement, and transformation are shown in Table 1. Pesticides and their metabolites are transported within ecosystems mainly through the water cycle. Precipitation, evaporation, runoff, leaching, macropore flow, and root uptake are the major flux pathways. Within the unsaturated and saturated soil zones and geologic strata, movement can be lateral, upward, or downward. These processes, as they operate in forested watersheds, are discussed in great detail by Anderson et al. [9] and by Crossley and Swank [10].

Biochemical, chemical, and physical processes that occur within the air-soil-geosphere continuum affect the gain or loss of pesticide residues within the system (Table 1). The importance of these processes is determined by individual pesticide characteristics, climatic factors, soil-water properties, and indigenous biota. These processes have been discussed in considerable detail elsewhere $[11,12]$. The purpose of this discussion is only to give the reader a brief overview of these key environmental fate processes.

\section{Pesticide characteristics}

The important properties that distinguish pesticides and their potential effects on theenvironment are listed in Table 2. These key physical-chemical parameters affect the rate of dissipation, as measured by half-life, and ultimately the potential environmental effects.

\section{Application}

The environmental effects are governed by toxicity (LC50, LD50) but are also strongly influenced by application conditions, including placement, system, formulation, rate, timing, and use pattern. Other things being equal, it is mainly the prescription, application, and execution that determine the potential severity of environmental impacts. There are almost infinite combinations of these factors to consider. The presence and size of buffers have a large effect on the potential impacts of pesticides because they are used as mitigation measures to reduce or prevent pesticide off-site movement. The needed buffer size is a function of the chemistry of each herbicide, the application system, physiography, and the sensitivity of water resources and aquatic ecosystems.

\section{Degradation}

Once a pesticide is applied, it is subjected to natural processes that eventually result in its disap- 
Table 1. Major water and pesticide processes affecting fate and transport in air, soil, and geologic environmental zones

\begin{tabular}{|c|c|c|c|}
\hline $\begin{array}{l}\text { Environmental } \\
\text { zone }\end{array}$ & Water & $\begin{array}{l}\text { Processes } \\
\text { addition }\end{array}$ & Pesticide loss \\
\hline Atmosphere & $\begin{array}{l}\text { Evaporation } \\
\text { Precipitation }\end{array}$ & $\begin{array}{l}\text { Application } \\
\text { Drift }\end{array}$ & $\begin{array}{l}\text { Photodecomposition } \\
\text { Condensation }\end{array}$ \\
\hline Plant & $\begin{array}{l}\text { Evapotranspiration } \\
\text { Precipitation } \\
\text { Runoff } \\
\text { Infiltration }\end{array}$ & $\begin{array}{l}\text { Decomposition } \\
\text { Volatilization } \\
\text { Drift }\end{array}$ & $\begin{array}{l}\text { Absorption } \\
\text { Photodecomposition } \\
\text { Drift } \\
\text { Washoff } \\
\text { Soil condensation }\end{array}$ \\
\hline Root zone & $\begin{array}{l}\text { Evaporation } \\
\text { Leaching } \\
\text { Root uptake }\end{array}$ & $\begin{array}{l}\text { Application } \\
\text { Erosion } \\
\text { Transport }\end{array}$ & $\begin{array}{l}\text { Chemical degradation } \\
\text { Biological degradation } \\
\text { Adsorption } \\
\text { Root uptake }\end{array}$ \\
\hline Vadose zone & Movement & Transport & $\begin{array}{ll}\text { Chemical } & \text { degradation } \\
\text { Biological } & \text { degradation } \\
\text { Adsorption } & \\
\text { Transport } & \end{array}$ \\
\hline Ground water & Movement & Transport & $\begin{array}{l}\text { Chemical degradation } \\
\text { Biological degradation } \\
\text { Adsorption } \\
\text { Transport }\end{array}$ \\
\hline
\end{tabular}

pearance. Pesticides are initially retained on-site by being deposited on foliage and litter surfaces, placed directly onto vegetation, applied within inert granule carriers, or absorbed onto soil surfaces. Their disappearance is a combination of two groups of processes-transport and degradation.

\section{Transport processes}

These processes include drift, foliar and stem washoff (also physical dislodgement), volatilization, plant uptake, leaching, surface runoff, and subsurface flow. Through them, pesticides move within and from a treated area, and from targets to water or nontarget organisms. All these movement processes are affected by a complex set of chemical, physical, climatic, hydrologic, edaphic, and biologic factors.

\section{Degradation processes}

Processes that degrade the chemical structures of pesticides include photodecomposition, microbial and plant metabolism, thermal degradation, and hydrolysis. These processes, along with those that transport herbicides, determine the degree to which a pesticide persists and moves in the environment. Some pesticides readily photodegrade, some do not, and some do so only in water. Many soil and water microorganisms can utilize pesticides as energy sources and break down these chemicals into simpler structures. Pesticides are also degraded into simpler compounds by physical-chemical processes like hydrolysis and by biochemical ones like metabolism in plants and animals.

\section{WATER-QUALITY IMPACTS}

\section{Environmental fate}

Herbicides. A large number of herbicides are registered by the U.S. Environmental Protection Agency (EPA), but fewer than a dozen account for the majority of silvicultural usage, in terms of both frequency and total applied amounts. These herbicides are 2,4-D, 2,4-DP, dicamba, fosamine, glyphosate, hexazinone, imazapyr, picloram, sulfometuron methyl, tebuthiuron, and triclopyr. Of these chemicals, the most commonly used are triclopyr, hexazinone, glyphosate, and 2,4-D. Herbicides used in seed orchards generally come from this same list. Those commonly used in nurseries include the former list as well as atrazine, hifenox, DCPA, diphenamid, napropamide, oxyfluorofen, sethoxydim, and simazine. Seed orchards and nurseries account for very little of the area treated and active ingredient (a.i.) used annually in the South. This review will focus on the herbicides that are in wide- 
Table 2. Physical, chemical, environmental, and toxicological parameters for pesticides used in conjunction with forest management or forest product manufacturing

\begin{tabular}{|c|c|c|c|c|c|c|c|c|c|}
\hline Pesticide & $\begin{array}{l}\text { Solubility } \\
\text { at } 25-\mathrm{c} \\
(\mathrm{mg} / \mathrm{L})\end{array}$ & $\begin{array}{l}\text { Half-life }^{a} \\
\text { (d) }\end{array}$ & $\begin{array}{c}\text { Photo- } \\
\text { degradation }\end{array}$ & $\begin{array}{l}\text { Microbial } \\
\text { degradation }\end{array}$ & Hydrolysis & Volatilization & $\begin{array}{c}\text { Adsorption } \\
\text { coefficient } \\
\left(K_{\mathrm{H}}\right)\end{array}$ & $\begin{array}{c}\mathrm{LD}^{\mathrm{b}}{ }^{\mathrm{b}} \\
(\mathrm{mg} / \mathrm{kg})\end{array}$ & $\begin{array}{l}\mathrm{LC} 50^{\mathrm{C}} \\
(\mathrm{mg} / \mathrm{L})\end{array}$ \\
\hline 2,4-D & $3,000,000^{d}$ & 28 & Minor & Yes & Yes & Yes & 0.5 & 375 & 168.0 \\
\hline Azinphosmethyl & 33 & 30 & Yes & Yes & Yes & No & 20.0 & 12 & 0.2 \\
\hline Carbofuran & 700 & 60 & NO & Yes & Yes & NO & 8.0 & 8 & 0.2 \\
\hline $\mathrm{Cu}-\mathrm{Cr}-\mathrm{As}$ & 50 & None & NO & No & No & NO & 5.0 & 50 & $>0.1$ \\
\hline Dicamba & 4,500 & 25 & No & Yes & No & No & 0.1 & 757 & 135.0 \\
\hline Fenvalerate & $<1$ & 35 & Yes & Yes & Yes & NO & 20.0 & $4 \$ 1$ & $>0.1$ \\
\hline Fosamine & $I, 790,000$ & I0 & No & Yes & No & NO & 20.0 & 24,400 & 278.0 \\
\hline Glyphosate & 12,000 & 60 & Minor & Yes & No & $\mathrm{L} 0 \mathrm{~W}$ & 16.5 & & \\
\hline Hexazinone & 33,000 & 30 & Yes & Yes & No & L $0 \mathrm{~W}$ & 0.2 & 1,690 & 370.0 \\
\hline Imazapyr & 15,000 & 30 & Yes & Yes & No & NO & 0.3 & 5,000 & 120.0 \\
\hline Lindane & 10 & 90 & Yes & Yes & No & Yes & 15.0 & 88 & \\
\hline Malathion & 145 & 20 & Yes & Yes & Yes & NO & 8.0 & 2,800 & 20.10 .1 \\
\hline Pentachlorophenol & 20 & 30 & NO & Yes & Yes & Yes & 8.0 & 210 & 0.1 \\
\hline Picloram & 430,000 & 60 & Yes & Yes & Yes & NO & 0.6 & 8,200 & 21.0 \\
\hline Sulfometuron & $300^{f}$ & I0 & No & Yes & Yes & No & 0.7 & 5,000 & 12.0 \\
\hline Triclopyr & 430 & 45 & Rapid & Yes & No & LOW & 1.5 & 630 & 148.0 \\
\hline
\end{tabular}

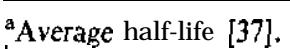

${ }^{b} \mathrm{LD} 50$, technical grade for rats; based on the formulation

${ }^{\mathrm{c}} \mathrm{LC} 50$ for bluegill sunfish, $96 \mathrm{~h}$.

${ }^{\mathrm{A}}$ Amine salt formulation.

Water solubility for potassium salt.

'Solubility at $\mathrm{pH} 7 ; 10 \mathrm{ppm}$ at $\mathrm{pH} 5$ 
spread use in forest ecosystems and have the best data bases.

Another paper in this volume discusses herbicide monitoring studies in southern forest ecosystems in some detail [13]. Some 24 studies are listed, and sampling matrices and measured peak concentrations are examined. The discussion here highlights several aspects of the behavior of herbicides in forested watersheds using hexazinone, the most studied of these chemicals.

Hexazinone is a selective triazine herbicide that is low in toxicity and risk to aquatic and terrestrial organisms, as established toxicity thresholds are not commonly exceeded in the actual use environment [14]. Because hexazinone is readily soluble in water, its susceptibility to off-site movement in surface runoff and leaching makes it a particularly useful chemical for study. Hexazinone's key physicalchemical biological parameters are shown in Table 2. It is degraded via microbial and photodecomposition pathways and is not prone to loss by volatilization. Its half-life is short, generally $<30 \mathrm{~d}$, but it can vary between two weeks and six months, depending on soil and climatic conditions. Some phytotoxic metabolites are produced by microbial degradation, but they are generally short-lived.

Hexazinone residue fate and transport in forested watersheds are better documented in the South than any of the other herbicides. Miller and Bace [IS] reported high concentrations (up to $2,400 \mu \mathrm{g} / \mathrm{L}$ ) from direct fall of hexazinone pellets into a perennial stream. The pellets were dropped when a helicopter overflew a streamside buffer zone on one pass. Concentrations fell within $24 \mathrm{~h}$ to $110 \mu \mathrm{g} / \mathrm{L}$ and by $10 \mathrm{~d}$ were down to $<10 \mu \mathrm{g} / \mathrm{L}$. In another aerial application in Tennessee, pellets were applied to $<20 \%$ of a large watershed, but no streams were overflown [16]. Consequently, hexazinone was never detected in stream flow during a seven-month period following that application.

Similar contrasts exist for ground applications of the same herbicide. In a detailed study in the upper Piedmont of Georgia, four ephemeral, firstorder watersheds were broadcast-treated with hexazinone pellets at a rate of $1.68 \mathrm{~kg} / \mathrm{h}$ ) [17]. Stream flow consisted only of storm runoff. For the next year, runoff from 26 storms was collected to determine hexazinone transport in stream flow (Fig. 1). Residues peaked in the first storm $(442 \mu \mathrm{g} / \mathrm{L})$ and declined steadily thereafter. Loss of hexazinone from the herbicide-treated sites averaged $0.53 \%$, with two storms accounting for nearly $60 \%$ of the off-site transport. Subsurface movement in base flow occurred two months after the hexazinone pel- let application, lasted for less than two weeks, and produced a short-term pulse with a peak of $24 \mu \mathrm{g} / \mathrm{L}$.

In contrast, hexazinone was applied to a watershed in Arkansas as a liquid spot application with somewhat different results [18]. The application rate for this study was slightly higher than that in the Georgia study, and the ephemeral channels were not treated. As a result, hexazinone residues were never detected in storm runoff. Base flow from this watershed continued to carry low levels of hexazinone $(<14 \mu \mathrm{g} / \mathrm{L})$ for over a year (Fig. 2). The total amount of herbicide transported out of the watershed was 2 to $3 \%$ of that applied, four to six times that reported by Neary et al. [17]. Similar concentrations $(6-36 \mu \mathrm{g} / \mathrm{L})$ to those of the Arkansas study have been measured in stream flow in several sets of spot treatments in Alabama and Georgia [13].

One aspect of the research on herbicide movement being conducted in the South is the determination of dynamics of transport in storm flow and base flow. There is a general understanding that most residue transport occurs in the first three to six storms $[7,17,19]$. In some instances no herbicide residues have been detected in storm flow $[16,18$, 20]; in others, residues have been delayed one to several months in baseflow [21]; in still others, such residues have occurred only in base flow [18]. Thus, a major question still exists concerning when to sample relative to storm hydrographs. Storm event duration and intensity, distance of residues from stream channels, routing, and mechanism of transport affect the timing of pesticide residue peaks. An example is shown in Figure 3 for sulfometuron methyl, the second storm after an aerial application of $0.42 \mathrm{~kg} / \mathrm{ha}$ to a $455-\mathrm{ha}$ watershed in Mississippi. The main peak of measured residue movement did not coincide with peak storm flow but occurred during baseflow recession and was intermittent.

The solution to this sampling problem depends on whether the objective is research or operational monitoring, and on understanding of the hydrology of specific watersheds. Operational monitoring programs are unlikely to invest the same amounts of resources in sampling and analysis that research typically does. A number of valid sampling techniques (grab, time, stage activated, flow proportional, etc.) can be used. The best choice is to sample with automated equipment on a flow-proportional basis and then analyze individual samples at storm peak, midway on the baseflow recession, and during post-storm base flow. Additional samples can then be analyzed to fill in the intervals as warranted. Simulation models can be useful as tools to guide sampling by estimating likely periods of pes- 


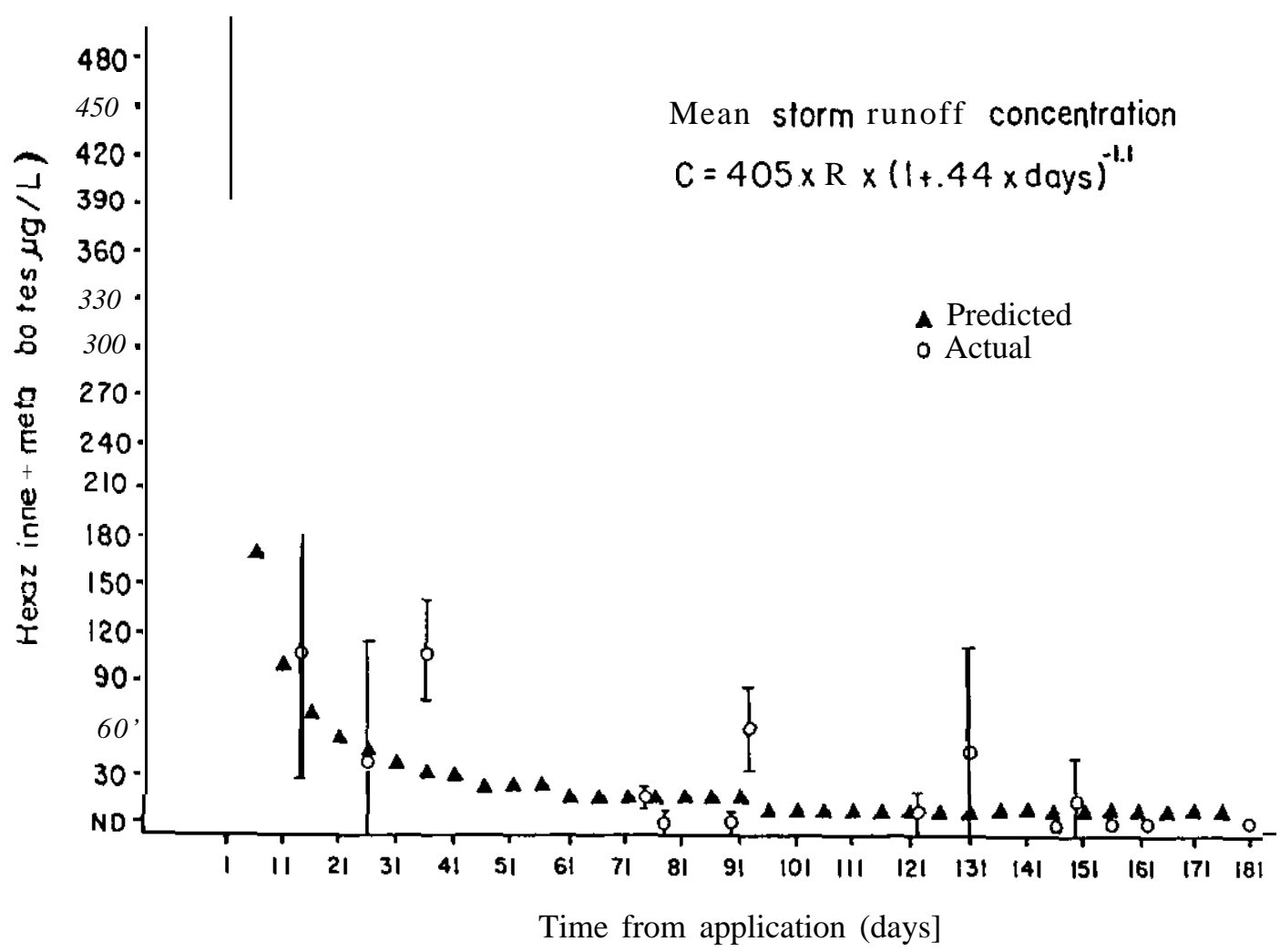

Fig. 1. Actual and predicted meanstorm runoff concentration of hexazinone after al $68-\mathrm{kg} /$ ha ground application of pellets in l-ha forest watersheds in northern Georgia (standard deviations indicated) [17] (reprinted with permission).

ticide movement. In the case of the storm shown in Figure 3, a 6-h, multiple-composite, automated schedule was manually overridden to trigger flowproportional sampling.

Insecticides. These chemicals are used mainly on special use areas such as seed orchards and nurseries. Wide-scale applications are infrequently used to control insect outbreaks like gypsy moth and the southern pine beetle. Some of the commonly used nursery and seed orchard insecticides include carbaryl, chlorpyrifos, diazinon, dimethoate, and fenvalerate. Acephate, diflubenzuron, dimilin, lindane, and trichlorfon are used in the control of large insect outbreaks. In addition to those already mentioned, azinphosmethyl, carbofuran, malathion, and permethrin are applied in seed orchards to control destructive cone and seed insects.

A series of studies have been conducted on seed orchards to examine off-site movement and nontarget organism impacts. Bush et al. [22] reported very high concentrations in surface runoff after a ground-seeder application of $19.0 \mathrm{~kg} / \mathrm{ha}$ of carbo- furan in the piedmont of Georgia (Fig. 4). This type of application involved the highest application rate of any forestry pesticide. Although concentrations reached as high as 7,820 $\mu \mathrm{g} / \mathrm{L}$ in 1981, carbonfuran residues did not persist from year to year and were variable between years, depending on climatic conditions relative to the insecticide applications.

Fungicides. These chemicals are used mainly in tree seedling nurseries and include benomyl, captan, chlorothalonil, dicloran, metalaxyl, maneb, thiram, and triadimefon. Very little in situ research on the environmental fate of these chemicals under actual nursery-use conditions was conducted until recently, when a large nursery-chemical human exposure and fate study was initiated. Other fungicides commonly used throughout the region that have a potentially greater impact on water quality include wood preservative chemicals like copperchromium-arsenic (CCA) and pentachlorophenol (PCP). Although these two compounds are not normally applied to forests, many wood preservative plants throughout the South are located within for- 


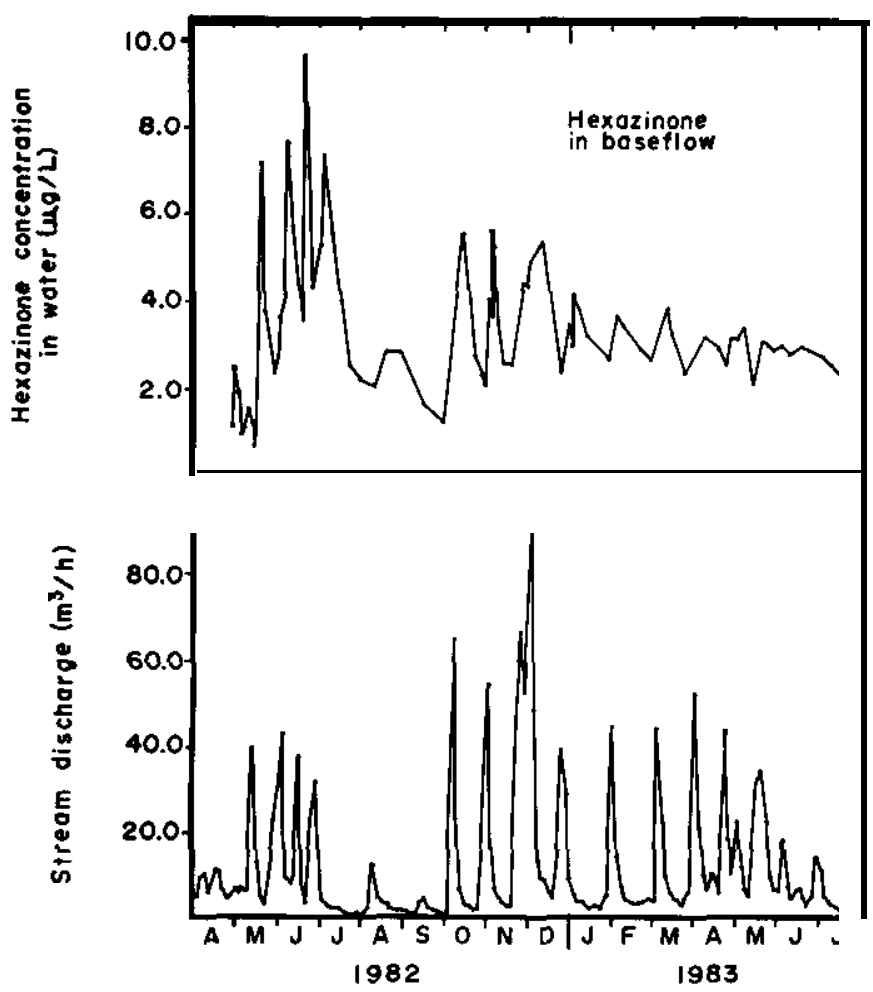

Fig. 2. Stream discharge and hexazinone in base flow after a spot application of $2.0 \mathrm{~kg} / \mathrm{ha}$ to I I .4-ha forest watersheds in Arkansas [IS] (reprinted with permission).

ested watersheds close to their wood resources. In some locations, CCA and PCP have caused major water-quality problems. These chemicals provide an interesting contrast, because one is biodegradable (PCP) and the other is not.

Transport of CCA and PCP was examined in an upper Piedmont watershed of northern Georgia that received surface runoff from a wood preservative treatment facility. Stream and pond bottom sediments (Fig. 5) contained significant quantities (up to $148 \mathrm{mg} / \mathrm{kg}$ ) of CCA [23]. Natural and artificial empoundments were important in retaining CCA in the headwaters. However, elevated levels of CCA were still detected $4 \mathrm{~km}$ downstream. Concentrations of PCP were high in the upper portion of the watershed $(365 \mu \mathrm{g} / \mathrm{L})$ and were affected by storm size and location within the watershed. During some storm flows, PCP concentrations exceeded the water-quality standard (I $\mu \mathrm{g} / \mathrm{L}) 4 \mathrm{~km}$ downstream (Fig. 6) and were detectable in a mediumsized reservoir [24].

Effect of buffer strips on pesticide movement. Buffer strips, or zones of undisturbed vegetation alongside riparian areas and other surface waters, are frequently employed as "best management practices" to reduce the impact of pesticides on aquatic ecosystems. The efficacy of buffer strips in mitigating pesticide transport into wetlands or riparian zones is quite varied due to the many factors that can affect pesticide transport. In virtually all of the environmental fate studies summarized in Table 3, no attempt was made to investigate the effects and functions of differing buffer strip sizes. Where buffer strips were used, other criteria determined the buffer strip width.

Pesticide chemistry, application rate, distribution method, buffer size, and weather conditions are very important in determining how well buffer strips work. In all cases listed in Table 3 where resulting stormflow or streamflow concentrations were high $(>100 \mu \mathrm{g} / \mathrm{L})[15,17,19,22,25]$, no buffer strips were used or the buffer was violated during the pesticide application. The lack of a buffer, plus the highest application rate (Table 3 ) produced the highest streamflow concentration $(7820 \mu \mathrm{g} / \mathrm{L})$ of all the listed studies [22]. 


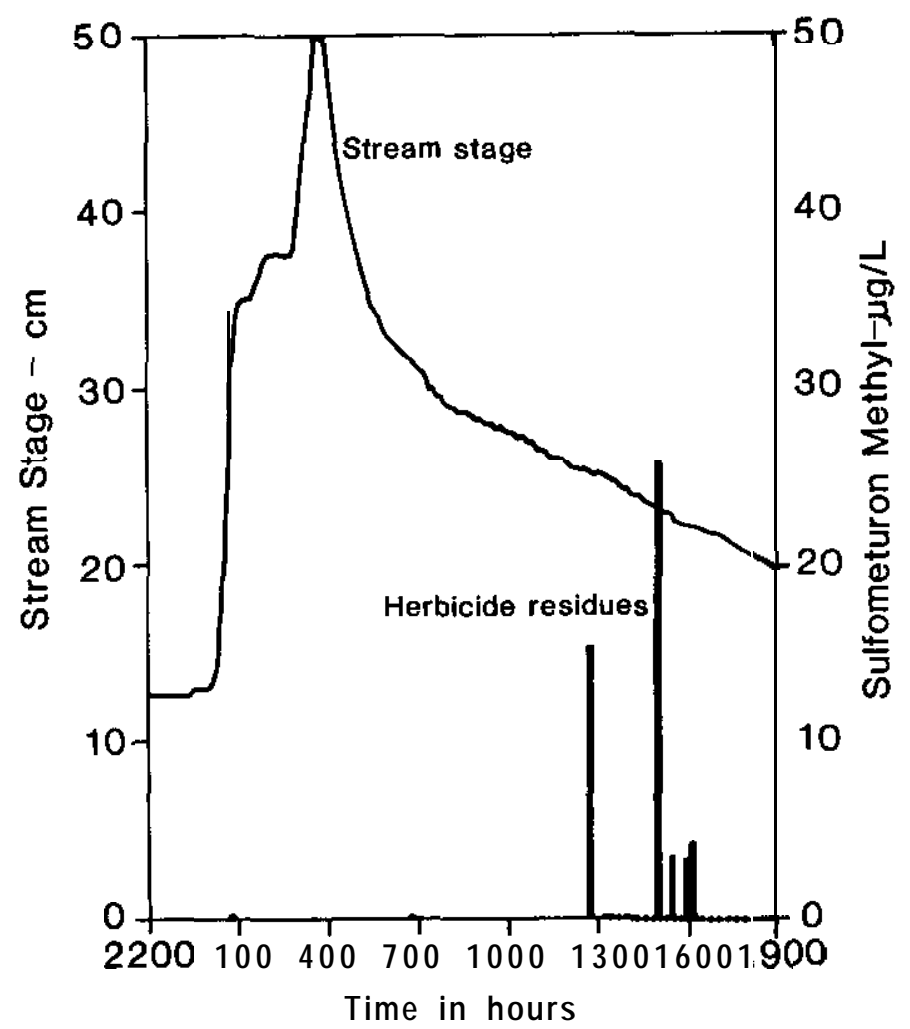

Fig. 3. Sulfometuron methyl in storm flow from 455-ha clear-cut watersheds in Mississippi following application of $0.42 \mathrm{~kg} / \mathrm{ha}$ by air.

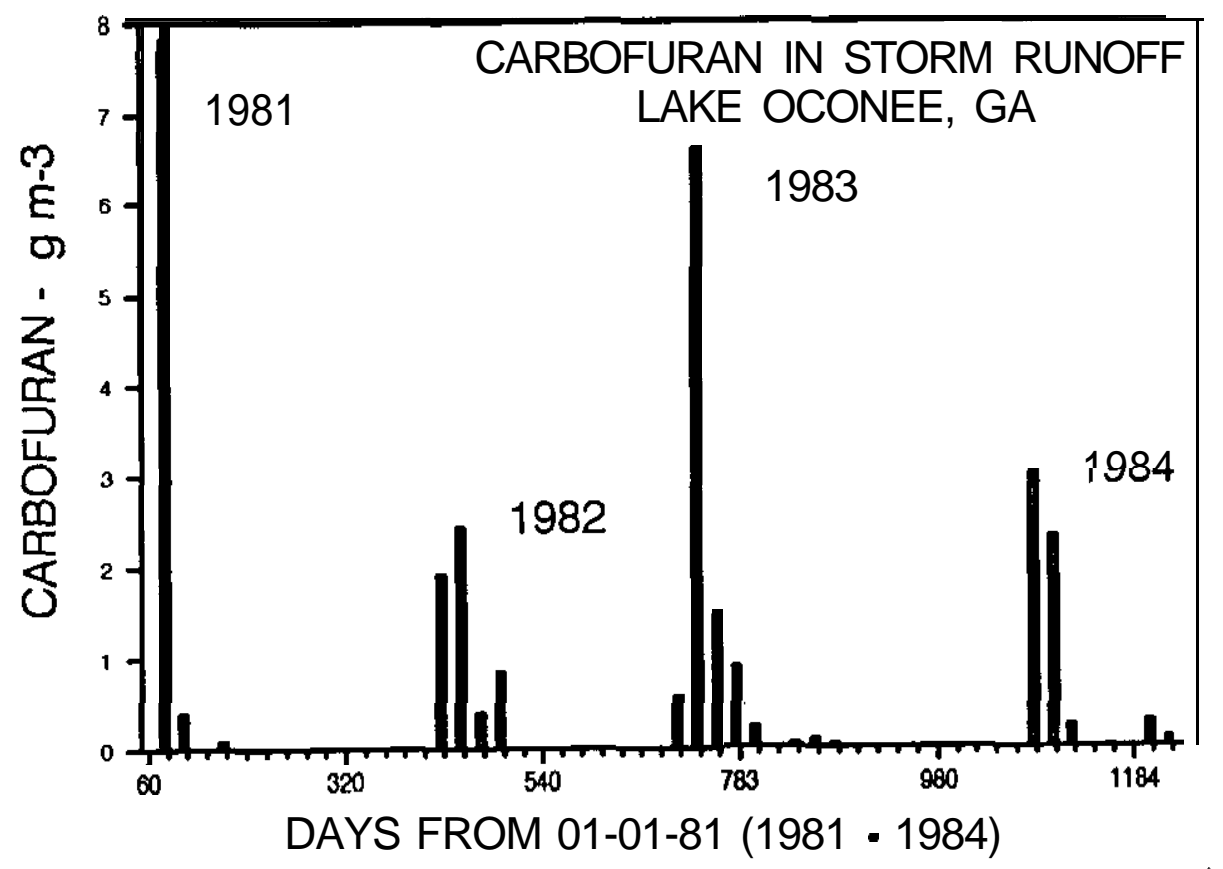

Fig. 4. Carbofuran in storm runoff from Z-ha watersheds on a pine seed orchard treated with $19.0 \mathrm{~kg} / \mathrm{ha}$ a.i. granular formulation by subsurface insertion, Lake Oconee, Georgia [22] (reprinted with permission). 
SEPTEMBER 30, 1982

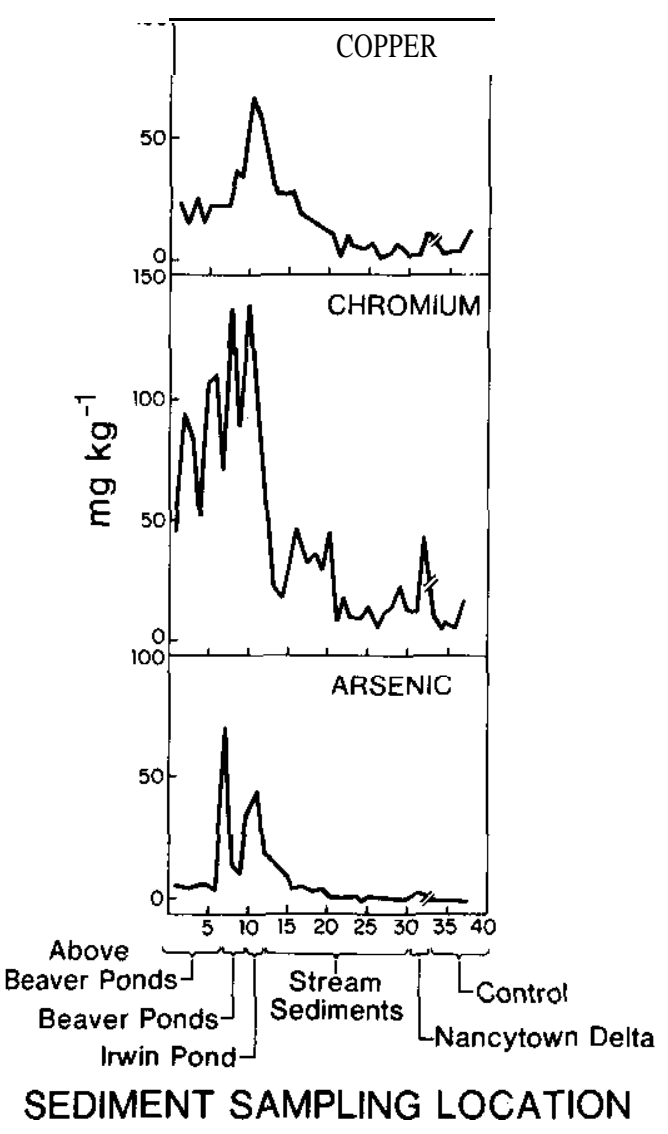

Fig. 5. Profile of $\mathrm{Cu}, \mathrm{Cr}$, and $\mathrm{As}$ in stream and pond bottom sediments downstream from a wood preservative plant, Nancytown Creek, Chattahoochee National Forest, Georgia [23] (reprinted with permission).

Generally speaking, buffer strips of $15 \mathrm{~m}$ or larger are effective in minimizing pesticide residue contamination of stream flow (Table 3). The user of buffer strips can keep pesticide residue concentrations within water-quality standards. However, they are not absolute, and one as large as $140 \mathrm{~m}$ did not keep residues out of a perennial stream $[21,26]$.

\section{HERBICIDE RESIDUES IN GROUND WATER}

Pesticide contamination of ground water has become a national priority environmental issue in the past few years as a result of growing incidents of residues being detected in well samples. In most of the southern region, rural residences are dependent on ground water for a water supply. Also, significant areas of the Coastal Plain utilize ground water for major municipal water sources. For the region as a whole, 98 to $100 \%$ of the rural popula- tion relies on ground water, as does 14 to $89 \%$ of the public water supply population [27]. Thus, it is important to address the issue of potential groundwater pollution from operational use of forestry pesticides.

In general terms, forestry use of pesticides poses a low pollution risk to ground water due to its dispersed nature, low frequency of application, and low rates. For instance, herbicide use in forestry is only $10 \%$ of agricultural usage and likely to occur only once or twice in rotations of 25 to 75 years. Application rates are generally low $(<2 \mathrm{~kg} / \mathrm{ha})$, and animal toxicities are low. Some of the silvicultural herbicides can affect nontarget plants at low concentrations $(<20 \mu \mathrm{g} / \mathrm{L})$ and could affect the quality of water for irrigation purposes. Within large watersheds where extensive ground water recharge occurs, intensive use of silvicultural herbicides would affect only $<5 \%$ of the area in any one year. The greatest potential hazard to ground water comes from handling concentrates (transport of formulations; storage; spillage during mixing; and loading, disposal. and rinsing of containers, to name several prominent sources), not operational application of diluted mixtures.

Regional, confined groundwater aquifers are not likely to be affected by normal use of silvicultural herbicides [28]. Surface, unconfined aquifers in the immediate vicinity of herbicide application zones have the most potential for some contamination. It is these aquifers that are directly exposed to leaching of residues from the root zone. This discussion will focus on the effect of silvicultural herbicide usage on surface aquifer contamination.

In the Georgia Piedmont, hexazinone was applied in a pellet formulation at a rate of $1.68 \mathrm{~kg} / \mathrm{ha}$ to four small $(<1-$ ha) first-order watersheds [17]. Subsurface movement of hexazinone in shallow, surface ground water was detected three to four months after application. Hexazinone concentrations in ground water entering perennial stream channels as base flow were very low $(<24 \mu \mathrm{g} / \mathrm{L})$ and did not persist for more than $30 \mathrm{~d}$. Bouchard et al. [18] reported a very different situation with hexazinone applied to a 11.5.ha watershed in Arkansas at $2.0 \mathrm{~kg} / \mathrm{ha}$. Hexazinone residues were consistently measured in ground water entering perennial stream channels for over a year after application; however, concentrations never exceeded $14 \mu \mathrm{g} / \mathrm{L}$. In South Carolina, application of $2.8 \mathrm{~kg} / \mathrm{ha}$ hexazinone did not produce any groundwater contamination in sandy soils where the water table ranged from 2 to $14 \mathrm{~m}$ below surface [29]. On a Florida site with similar soils and a lower application rate $(1.7 \mathrm{~kg} / \mathrm{ha})$, hexazinone was detected in surficial, unconfined 

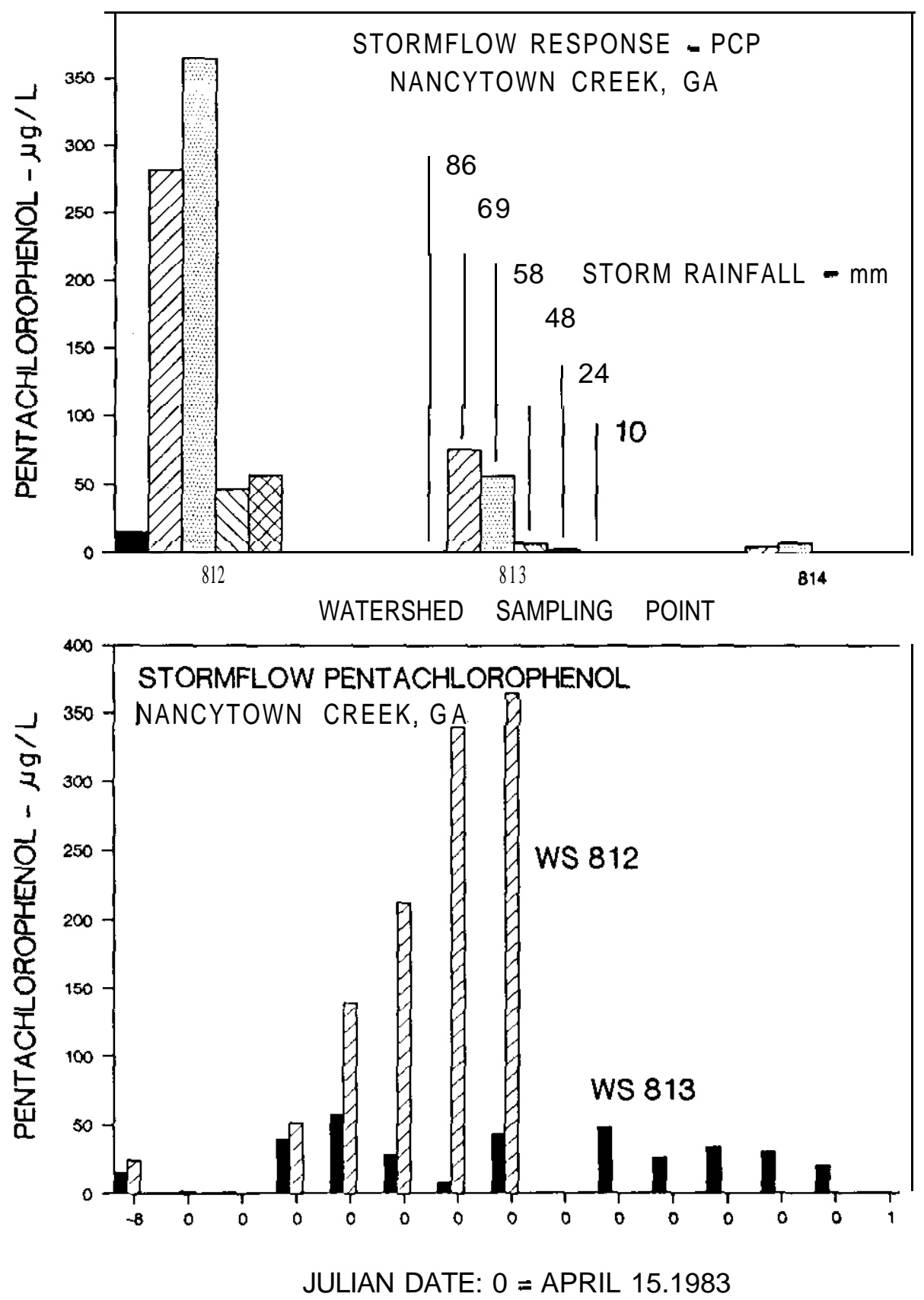

Fig. 6. Pentachlorophenol in Nancytown Creek, storm flow downstream from a wood preservative plant, Chattahoochee National Forest, Georgia [24] (reprinted with permission).

ground water (17-35 $\mu \mathrm{g} / \mathrm{L})$ but not until a year later. These concentrations were well below a suggested water-quality standard for hexazinone 300 $\mu \mathrm{g} / \mathrm{L})$ and $>10 \mathrm{~km}$ from any domestic well. Dilu- tions, both temporal and spatial, also greatly reduce the significance of these detected hexazinone concentrations.

Sulfometuron methyl was applied as water-dis- 
Table 3. Effect of buffer strips on forestry pesticide concentrations in stream flow (from USDA Forest Service [37])

\begin{tabular}{|c|c|c|c|c|c|c|c|}
\hline \multirow[b]{3}{*}{ Pesticide } & \multicolumn{2}{|c|}{ Application } & \multirow{2}{*}{\multicolumn{2}{|c|}{ Landscape }} & \multicolumn{2}{|c|}{ Pesticide } & \multirow[b]{3}{*}{ Ref. } \\
\hline & \multirow{2}{*}{$\begin{array}{l}\text { Rate }^{\mathrm{a}} \\
(\mathrm{kg} / \mathrm{ha})\end{array}$} & \multirow[b]{2}{*}{ System } & & & Buffer ${ }^{b}$ & Peak & \\
\hline & & & Type & Stream & (m) & $(\mu \mathrm{g} / \mathrm{L})$ & \\
\hline Azinphosmethyl & 3.4 & Air spray & $\mathrm{P}^{\mathrm{c}}$ & $E C^{d}$ & 0 & 1,540 & [22] \\
\hline DDT & 1.0 & Air spray & A M & $\mathrm{PS}$ & 0 & $<1$ & [6] \\
\hline Carbofuran & 19.0 & Ground pellet & $\mathrm{P}$ & $\mathrm{EC}$ & 0 & 7,820 & [22] \\
\hline Fenvalerate & 0.3 & Air spray & $\mathrm{P}$ & PS & 0 & 0 & [22] \\
\hline Hexazinone & 2.0 & Ground spotgun & $0 / 0$ & PS & 1 & 9 & [18] \\
\hline Hexazinone & 1.7 & Air pellet & TLP & PS & 20 & 0 & [16] \\
\hline Hexazinone & 1.7 & Ground pellet & $\mathrm{P}$ & EC & 0 & 442 & [17] \\
\hline Hexazinone & 1.8 & Air pellet & $\mathrm{P}$ & PS & 0 & 2,400 & {$[15]$} \\
\hline Lindane & 8.0 & Ground spray & $\overline{\mathrm{P}}$ & $\mathrm{EC}$ & 30 & 0 & [26] \\
\hline Picloram & 5.0 & Ground pellet & A M & PS & 140 & 10 & [21] \\
\hline Picloram & 5.6 & Air pellet & UCP & EC & 0 & 241 & [25] \\
\hline Sulfometuron methyl & 0.4 & Ground spray & LCP & $\mathrm{EC}$ & 5 & 7 & [19] \\
\hline m. & 2.0 & Ground spray & LCP & $\mathrm{EC}$ & $j$ & 2 & [20] \\
\hline
\end{tabular}

"Active ingredient rate.

${ }^{b}$ Width either side of stream channel.

"Physiographic repin": LCP = lower Coastal Plain; UCP = upper Coastal Plain; AM = Appalachian Mountains: $\mathrm{P}=$ Piedmont; $\mathrm{TLP}=$ Tennessee low plateaus; $\mathrm{O} / \mathrm{O}=$ Ozark/Ouachita mountains.

'Stream designation: $\mathrm{EC}=$ ephemeral channel; $\mathrm{PS}=$ perennial stream.

persible granules and pellets to small (4-ha) watersheds in Florida with a 5-m streamside buffer strip [19]. Residues of sulfometuron methyl detected in stream flow were low in concentration $(<7 \mu \mathrm{g} / \mathrm{L})$, did not persist beyond $7 \mathrm{~d}$, and did not penetrate to shallow ground water $(<1 \mathrm{~m}$ deep). An application of a structurally similar herbicide, metsulfuron methyl, to a similar site in Florida also did not leach into shallow ground water (J.L. Michael, personal communication). Both chemicals (sulfonylureas) are subject to rapid hydrolysis in acidic forest soils.

Triclopyr was applied to small watersheds (4 ha) in Florida in both the amine $(2.0 \mathrm{~kg} / \mathrm{ha})$ and the ester $(\mathrm{I} .6 \mathrm{~kg} / \mathrm{ha})$ formulations by ground sprayer. Monitoring of both stream flow and surface ground water $(<1 \mathrm{~m}$ deep) for five months following application did not reveal any detectable residues of triclopyr [20].

Application of picloram as a pellet formulation to steep watersheds of the Appalachian Mountains produced ephemeral ground water contamination [21]. Picloram was manually broadcast at a rate of $5.0 \mathrm{~kg} / \mathrm{h}$ a to $17 \%$ of a 30 -ha watershed. Residues of the herbicide were measured in soil solution $(<1.5 \mathrm{~m} \mathrm{depth})$ on the treatment site at concentrations up to $350 \mu \mathrm{g} / \mathrm{L}$ at a depth of $30 \mathrm{~cm}$ and $<30$ $\mu \mathrm{g} / \mathrm{L}$ at $120 \mathrm{~cm}$ (Fig. 7). A 100-m buffer strip between the application area and a first-order peren- nial stream reduced picloram concentrations in base flow (surface ground water) down to sporadic peaks of $<10 \mu \mathrm{g} / \mathrm{L}$ during a 17 -month monitoring period. Intensive sampling of a spring immediately below the picloram-treated area measured only trace concentrations.

An aerial application of pelleted picloram (5.0 $\mathrm{kg} / \mathrm{ha}$ ) in the upper Coastal Plain of Alabama resulted in a streamflow concentration of $50 \mu \mathrm{g} / \mathrm{L}$ during the treatment and a peak stormflow level of $241 \mu \mathrm{g} / \mathrm{L} 14 \mathrm{~d}$ later [25]. Picloram concentrations were $>10 \mu \mathrm{g} / \mathrm{L}$ for the first 100 dafter treatment and then $<2 \mu \mathrm{g} / \mathrm{L}$ after $140 \mathrm{~d}$, through about one year. Streamflow concentrations were orders of magnitude below toxic levels for animals but were in the toxic range $(>10 \mu \mathrm{g} / \mathrm{L})$ for sensitive plants.

\section{MODEL VERIFICATION}

Pesticide fate data from studies in southern forest ecosystems are being used to verify environmental fate models such as PRZM (pesticide root zone model), CREAMS (chemicals, runoff, and erosion from agricultural management systems), GLEAMS (groundwater loading effects of agricultural management systems), and CMLS (chemical movement in layered soils). The availability of high-powered desktop and laptop computers as well as validated models represents a considerable advance over the past decade. Both forestry managers and research- 


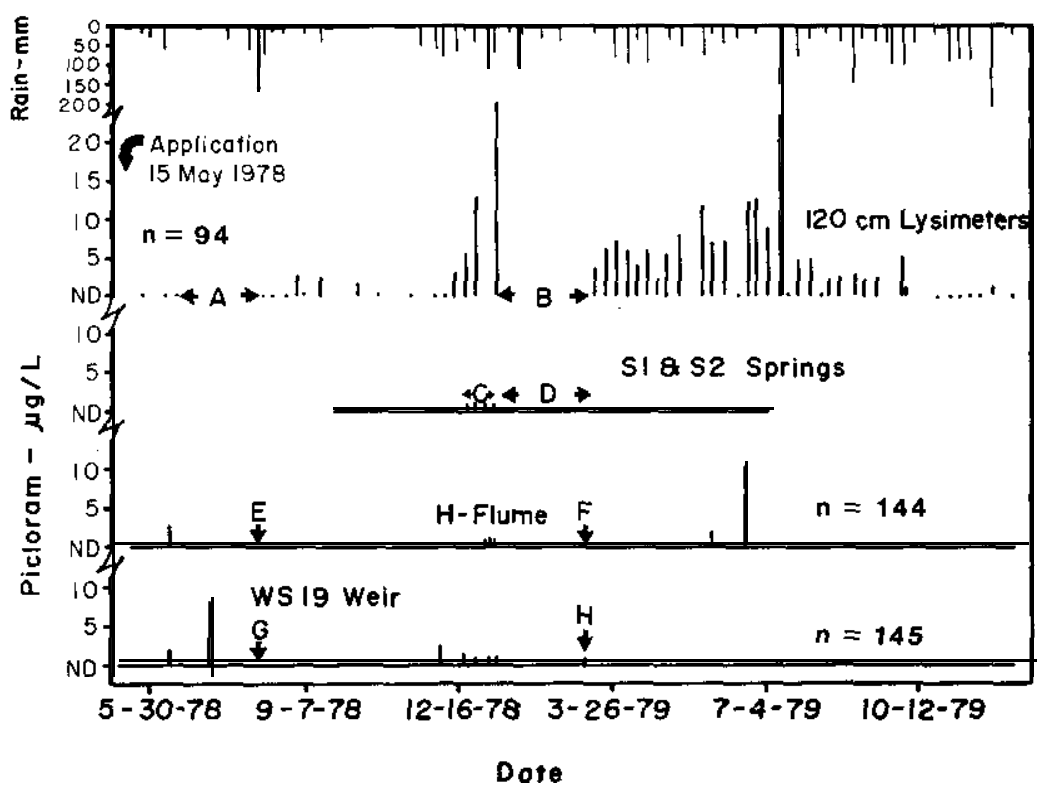

Fig. 7. Picloram in soil water on-site, in springs (S1 and S2) $140 \mathrm{~m}$ downslope, and in stream flow from IO-ha (Hflume) and 28-ha (WS 19 weir) Appalachian Mountain forest watersheds after application of $5.0 \mathrm{~kg} / \mathrm{ha}$ of pelleted formulation to a 4-ha site [21] (reprinted with permission).

ers now have excellent tools to aid in understanding and predicting pesticide movement in forest ecosystems.

Dowd et al. [30] discuss the use of and validation studies of PRZM and CREAMS in more detail. The CREAMS model has been used to develop water-quality risk assessments for seed orchards treated with carbofuran, azinphosmethyl, fenvalerate, and permethrin [31]. In Table 4, fishkill-event probabilities in a lake adjacent to a central Georgia seed orchard were calculated on the basis of CREAMS simulations using site-specific soils/hydrologic parameters, month of application, insecticide rate, LC50 concentrations, and 30 years of climatic data. The simulations indicated that risks can be lowered by appropriate selection of chemicals and by avoiding months that coincide with large runoff events and fish migration into lake shallows (i.e., January-March for carbofuran). Crawford et al. [32] evaluated the GLEAMS model for carbofuran in an Appalachian pine seed orchard and found close agreement between field data and simulations for initial residue movement, peak timing, and dissipation time.

\section{AIR QUALITY}

The common use of brown-and-burn techniques for hardwood weed control before planting cutover stands in the South, as well as the occurrence of wild fires in insecticide-treated stands, has raised concerns about the effects of burning on the pesticide content of air. Studies conducted on herbicides and insecticides indicate that hot fires $\left(>500^{\circ} \mathrm{C}\right)$ thermally degrade most pesticides (Table 5) [33-35]. Smoldering fires $<500^{\circ} \mathrm{C}$ have the potential to volatilize significant amounts of some pesticides. With hot fires, most pesticide residues are thermally degraded. Exposure analyses have indicated that burning, even under conditions of smoldering fires that have the potential to volatilize pesticide residues, does not result in any significant human health risk increases [34]. This is especially the case because individual stands are usually not treated with pesticides and burned more than once a rotation of 25 to 75 years.

Exposure analyses were conducted for dustborne pesticide particles in pesticide-treated, mixed hardwood-pine stands [36]. Here the concern was for additional exposure to forestry workers conducting other silvicultural operations subsequent to a pesticide application. Although soil-adsorbed pesticides can become entrained in dust stirred up by heavy equipment operation, the herbicides (2,4-D, dicamba, dichlorprop, hexazinone, picloram, and triclopyr) and insecticides (chlorpyrifos, fenitrothion, and lindane) involved in the exposure anal- 
Table 4. CREAMS generated probabilities for fish kill events in an adjacent lake for single and multiple applications of carbofuran, azinphosmethyl, fenvalerate, and permethrin to control cone and seed insects on a loblolly pine seed orchard in central Georgia (adapted from Dowd et al. [30])

\begin{tabular}{lcccc}
\hline Insecticide & Method & $\begin{array}{c}\text { Application } \\
\text { date }\end{array}$ & $\begin{array}{c}\text { Rate } \\
\text { (kg a.i./ha) }\end{array}$ & $\begin{array}{c}\text { Fish-kill-event } \\
\text { probability }^{\mathrm{a}}\end{array}$ \\
\hline Carbofuran & Soil & Dec. & 19.0 & 0.29 \\
& & Jan. & 19.0 & 0.39 \\
& & Feb. & 19.0 & 0.57 \\
Azinphosmethyl & Mar. & 19.0 & 0.59 \\
& \multirow{2}{*}{ Aerial } & Apr. & 19.0 & 0.33 \\
& & Apr. & 3.4 & 0.03 \\
& & May & 3.4 & 0.03 \\
& & June & 3.4 & 0.02 \\
Fenvalerate & July & 3.4 & 0.04 \\
& Aurial & Aug. & 3.4 & 0.04 \\
& & Sep. & 3.4 & 0.02 \\
& & Apr. & 0.84 & 0.02 \\
& & May & 0.84 & 0.02 \\
Permethrin & June & 0.84 & 0.02 \\
& & July & 0.84 & 0.02 \\
& Aerial & Aug. & 0.84 & 0.02 \\
& & Apr. & 0.78 & $<0.001$ \\
& & June & 0.78 & $<0.001$ \\
& & AUK. & 0.78 & $<0.001$ \\
\hline
\end{tabular}

'Probability of stormflow concentrations equaling or exceeding the LC50 level for bluegills (Lepomis macrochirus) at the edge of the seed orchard.

yses did not indicate any potential for increased exposure risks. The margin of safety (MOS) for daily exposure of all the tested pesticides exceeded 200. Generally, a MOS $>100$ is considered safe for even pesticide-sensitive individuals.

Table 5. Recovery of pesticide residues volatilized from blocks of wood heated at $20^{\circ} \mathrm{C} / \mathrm{min}$ to $500^{\circ} \mathrm{C}$

(slow combustion) and inserted directly into $500^{\circ} \mathrm{C}$ temperatures (rapid combustion) (from Bush et al. [33,34] and Neary et al. [35])

\begin{tabular}{|c|c|c|c|}
\hline \multirow[b]{2}{*}{ Pesticide } & \multicolumn{3}{|c|}{ Percentage recovery } \\
\hline & Slow & combustion" & Rapid combustion ${ }^{b}$ \\
\hline Chlorpyrifos & & 28.0 & 4.2 \\
\hline $2,4-D$ & & 88.9 & 1.6 \\
\hline Dicamba & & 91.5 & 32.1 \\
\hline Dichlorprop & & 100.0 & 6.5 \\
\hline Hexazinone & & 11.0 & 0.0 \\
\hline Lindane & & 43.0 & $41.0^{\mathrm{c}}$ \\
\hline Picloram & & $<0.1$ & $<0.1$ \\
\hline Triclopyr & & 68.0 & $c 0.1$ \\
\hline
\end{tabular}

'Wood samples heated at $20^{\circ} \mathrm{C} / \min$ to $500^{\circ} \mathrm{C}$. ${ }^{\circ}$ Wood samples immediately inserted into $500^{\circ} \mathrm{C}$. 'Recovery drops to nearly zero with $600^{\circ} \mathrm{C}$.

\section{INDIRECT EFFECTS}

The indirect effects of pesticide use in forest ecosystems have been examined rarely in any systematic manner or to a sufficient degree of detail. There is a considerable body of knowledge about direct effects on target pest organisms and on general toxicity of these chemicals. Although most direct human health effects are well known, the more subtle indirect effects remain a fertile ground for study [37]. Similarly, as indicated in this paper, there is a growing body of knowledge on the direct effects of pesticide use on water quality in forested watersheds. Water-quality changes that are secondary to the application of pesticides and not related to chemical contamination can occur. In addition, there can be indirect effects on flora and fauna populations that are not directly related to some toxicological response. For the most part, these responses to pesticide applications are not well known. Several examples of indirect effects are examined here to elucidate the types and ranges of water-quality and biotic responses.

Neary et al. [38] reported both positive and negative indirect water-quality effects from the application of $1.68 \mathrm{~kg} / \mathrm{ha}$ of hexazinone to a mixed 
hardwood-pine stand in northern Georgia.. Nitrate nitrogen $(\mathrm{NO},-\mathrm{N})$ concentrations in storm flow increased peak NO,-N concentration $(5,328 \mu \mathrm{g} / \mathrm{L})$ and exceeded peaks measured for other types of forest disturbance in the Southeast by one to two orders of magnitude (Fig. 8). Downstream water quality was not adversely affected because the NO,-N standard was not exceeded and the excess pulses did not persist longer than two years. On the positive side, the use of hexazinone for site preparation reduced sediment yields to the ephemeral stream channels. The total first-year sediment yield for hexazinone-treated watersheds averaged 170 $\mathrm{kg} / \mathrm{ha}$, close to the $100 \mathrm{~kg} / \mathrm{ha}$ natural sediment yields common in undisturbed forested watersheds in the South. By contrast, mechanical site preparation can produce first-year sediment yields in the

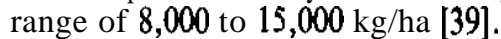

Both terrestrial and aquatic invertebrates are good indicators of environmental changes, but their responses to pesticide applications in forest ecosystems are not well studied. Mayack et al. [40] examined aquatic macroinvertebrates in a second-order stream below a hexazinone application site. Although temporal variations in taxa abundance were distinctly evident, there was no evidence that the herbicide altered either taxa abundance or diversity.
On the other hand, terrestrial macroinvertebrate abundance was reduced during the summer months on hexazinone-treated watersheds. This reduction was primarily due to a physical effect of drying out of the forest floor after defoliation of the forest overstory and understory. Wallace et al. [41] reported that the introduction of malathion to a first-order Appalachian Mountain stream directly reduced insect populations to $<10 \%$ of a control stream. Two indirect effects were noted thereafter. Leaf breakdown rates in the stream were significantly reduced, and the transport of fine particulate organic matter was reduced to $25 \%$ of that of an untreated control stream system. Downstream aquatic populations dependent on fine particulate organic matter transport could be indirectly affected as well.

Biodiversity is another example of where indirect effects of forestry pesticide use have not been adequately studied. A substantial body of literature exists on the efficacy of various herbicides in controlling both herbaceous and woody competition. However, very few studies have examined the impacts of herbicide on plant diversity. Neary et al. [42] demonstrated that herbicides can reduce the total number of plant species. Figure 9 indicates that after two separate herbicide applications (metsul-

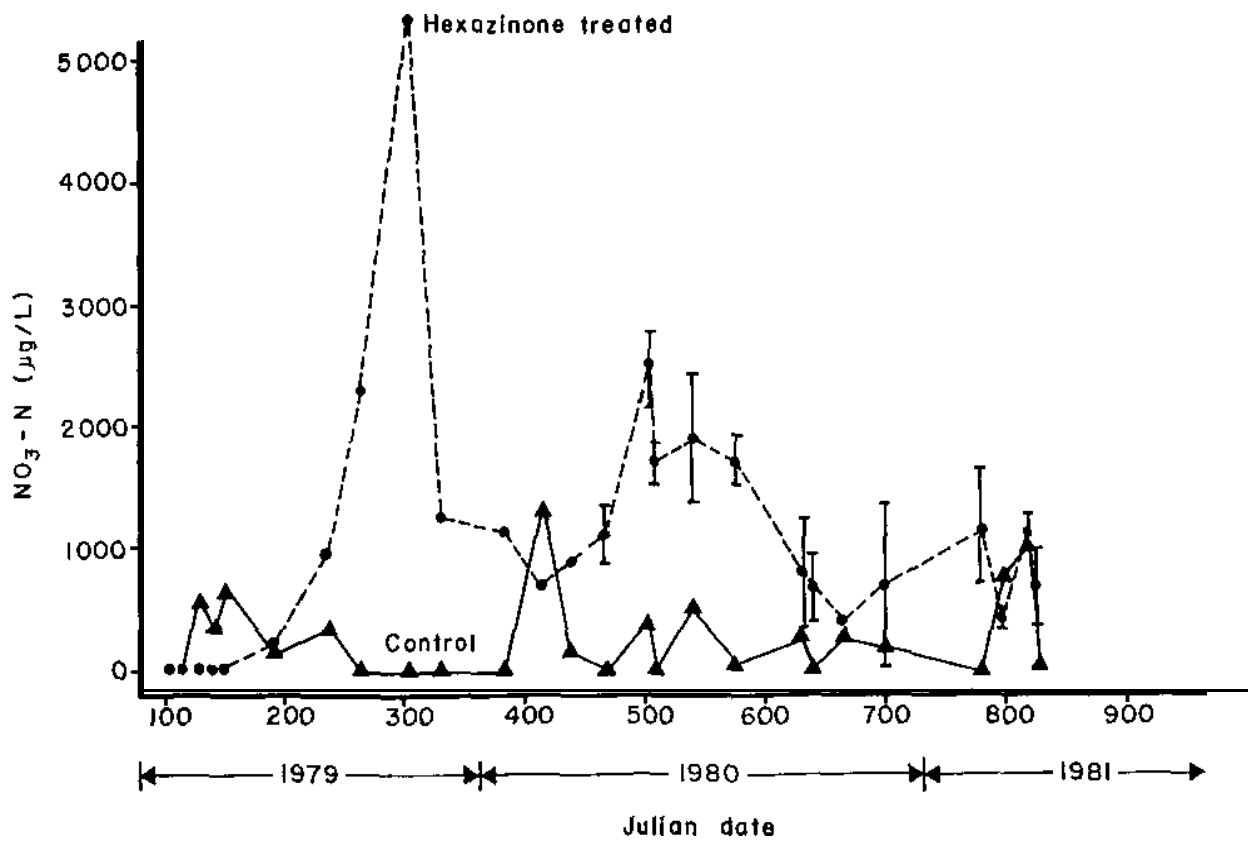

Fig. 8. Nitrate nitrogen in storm runoff from 1-ha forest watersheds in northern Georgia after an application of 1.68 $\mathrm{kg} / \mathrm{ha}$ hexazinone pellets to eliminate a hardwood overstory and from an untreated control watershed [38] (reprinted with permission). 
a.

HERBICIDE EFFECT ON SPECIES DIVERSITY

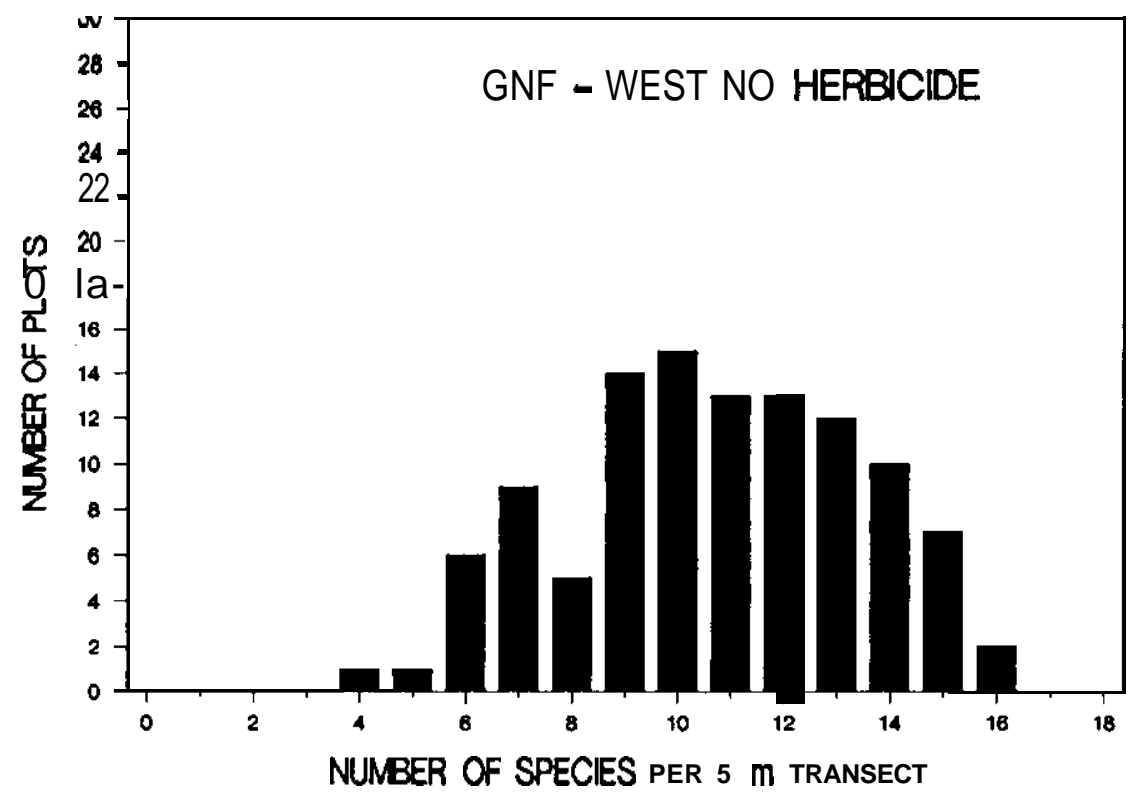

b. HERBICIDE EFFECT ON SPECIES DIVERSITY

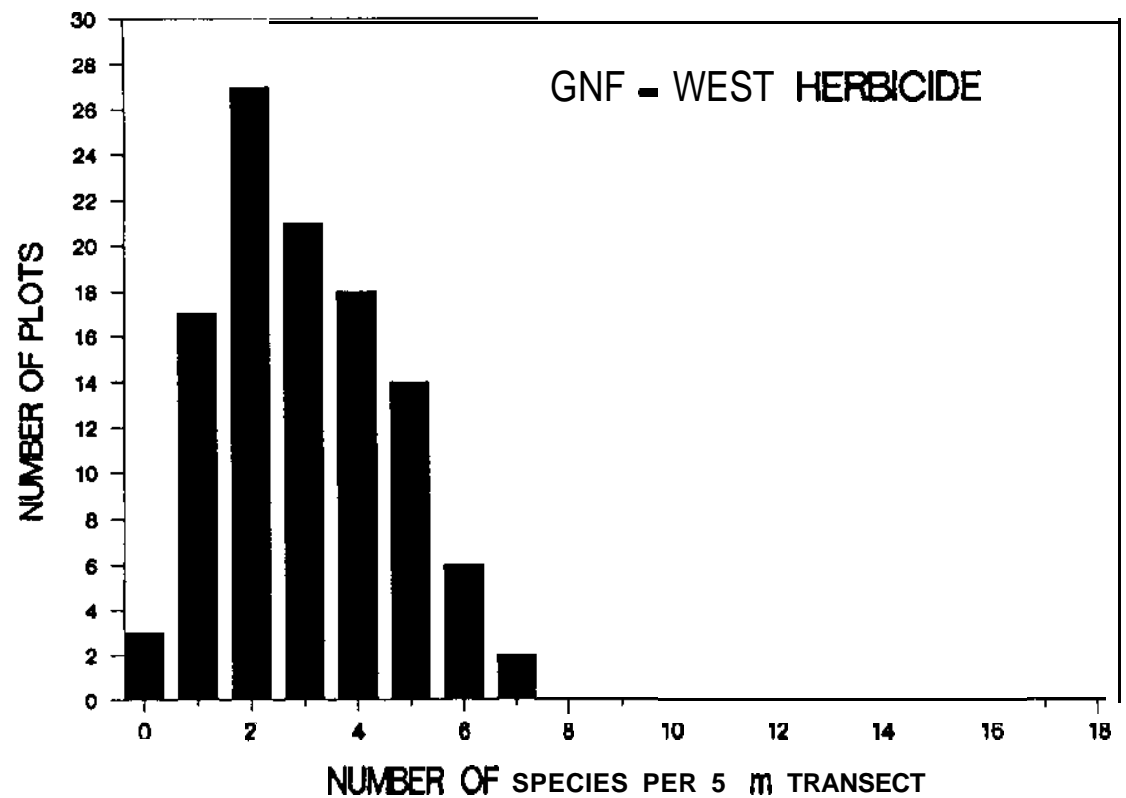

Fig. 9. Herbicide effects on plant species numbers occupying a flatwoods Spodosol in the northern Florida coastal plain four years after site preparation, herbicide application, and tree planting: (a) no herbicide used and (b) with one application of sulfometuron methyl and one of triclopyr. 
furon methyl and triclopyr) to a Coastal Plain flatwoods site in Florida, there were fewer plant species per transect. The herbicides put selective pressure on the plant community and eliminated some of the rarer species. These reductions in species numbers, as well as elimination of rare or important individual species, constitute some of the critical issues in the biodiversity debate.

\section{CUMULATIVE EFFECTS}

Future research is critically needed in the area of cumulative effects of pesticide use in forest ecosystems $[37,43,44]$, including the subjects of water quality, human health, invertebrates, reptiles, amphibians, wildlife, and biodiversity. Some research has produced data that can be used for limited cumulative effects analyses [17]. In one study, nested watersheds of 1,10 , and 100 ha allowed examination of hexazinone residue dilution in progressively larger watersheds. Although there was a two-ordersof-magnitude (100-fold) increase in watershed area (1-100 ha), the peak hexazinone concentration was reduced only one order of magnitude $(44-442 \mu \mathrm{g} / \mathrm{L})$. Some localized carbofuran-related fish mortality was observed in narrow bay heads of a power reservoir adjacent to a pine seed orchard in Georgia [22]. Fish sampled in shallows near the seed orchard and in more remote parts of the impoundment were impacted more by agricultural insecticides used upstream. The pesticide burdens of all the sampled fish reflected the cumulative effect, both in time and in distance, of persistent pesticides used mainly in agriculture. However, most pesticide fate research conducted in forest ecosystems before 1990 did not address the cumulative effects aspects of water quality, much less all of the other facets of this important environmental issue.

\section{SUMMARY AND CONCLUSIONS}

This paper reviewed the research progress of a decade on the topic of environmental fate, transport, and effect of pesticides used within forest ecosystems of the southern United States. Considerable information has been gathered on important processes controlling transport of pesticides, waterquality impacts, indirect effects, cumulative effects, air-quality impacts, and the role of simulation models in predicting pesticide movement. This information has been crucial in supporting regional environmental impact statements.

Although environmental fate and effects data are required for registration of all pesticides, some chemicals (e.g., hexazinone, picloram, carbofuran) have more extensive field study-based water-quality data sets. Buffer strips (untreated riparian zones) are particularly effective in keeping peak streamflow and stormflow concentrations short in duration and $<500 \mu \mathrm{g} / \mathrm{L}$. Most peak pesticide residue concentrations are associated with storm runoff and occur during the first one to four storm events, but are not always associated with hydrograph peaks. Under some hydrologic conditions, residue movement occurs only with surface runoff during storms, and base flows are not affected. Even where pesticide movement occurs continuously in base flows, 48- and 96-h LC50 concentrations have not been measured for any of the pesticide studies.

Very little cumulative effects research has been conducted to date because few studies were designed a priori to assess these effects. Several studies that collected cumulative effects data demonstrated that peak residue concentrations in forest watersheds do not necessarily decrease in the same proportions as area dilutions. Also, in watersheds with mixed land uses (e.g., forestry, agricultural, urban, etc.), the cumulative effects of agricultural pesticides on aquatic populations can easily override those of forestry pesticides due to gross differences in use frequency and application rates.

The effects of burning on 2,4-D, picloram, hexazinone, dichlorprop, triclopyr, lindane, and chlorpyrifos residues in smoke were assessed and risk analyses developed. Smoldering fires $\left(<500^{\circ} \mathrm{C}\right)$ volatilize the highest proportion of residues, but these residues are not large enough components of wood smoke to cause adverse health effects in closed environments, much less in open forests. Hot fires $>500^{\circ} \mathrm{C}$ thermally degrade most forestry pesticides, with the most resistant ones decomposing at temperatures $>600^{\circ} \mathrm{C}$ - well below the temperatures of well-developed forest fires or wood-stove fires.

Although research on the indirect effects of forestry pesticides is incomplete, both positive and negative effects have been measured. Although application of herbicides can temporarily increase nitrate nitrogen losses in stream flow, sediment yields are greatly reduced. Because sediment is the main nonpoint source pollutant in forest and other ecosystems, this is an effect of major significance. Although there is no evidence that herbicides adversely affect aquatic invertebrate populations, insecticides can do so dramatically and in turn produce indirect effects such as the reduction in stream transport of fine particulate organic matter. Whereas forestry herbicides produce short-term reductions in plant diversity, long-termeffects are still poorly understood.

Simulation models such as PRZM, CREAMS, and GLEAMS are becoming useful in predicting 
forestry pesticide movement and to guide monitor-

They are showing promise as tools to guide pesticide selection based on risks to water quality and to nontarget organisms. However, much more work is needed on validating these models in forest ecosystems.

Examination of limited ground water data sets indicates that forestry pesticides do not pose a significant risk to water quality due to infrequent use. The handling of concentrated chemicals presents the greatest risk, and then only to isolated areas, not wide landscapes. Although in situ information on all forestry-use pesticides is still incomplete and more research is needed to fill data gaps, the conclusion is that normal pesticide use in forest ecosystems does not pose a significant adverse risk to environmental quality.

\section{REFERENCES}

Stone, E.L. ed. 1983. Proceedings, Managed Slash Pine Ecosystem. University of Florida, Gainesville, FL, June 9-11,1981.

2 Kellison, R.C. and S. Gingrich, eds. 1982. Proceedings, Loblolly Pine Ecosystem (East Region). North Carolina State University, Raleigh, NC, December 8-10.

Riekerk, H., D.G. Neary and W.T. Swank. 1989. Magnitude of upland silvicultural nonpoint source pollution in the South. In D.D. Hook and R. Lea, eds., Proceedings, The Forested Wetlands of the Southern United States. General Technical Report SE50. USDA Forest Service, Asheville, NC, pp, 8-18.

4 Neary, D.G., L.A. Morris and B.F. Swindel. 1984. Site preparation and nutrient management in southern pine forests. In E.L. Stone, ed., Forest Soils and Treatment Impacts, Proceedings, Sixth North American Forest Soils Conference, Knoxville, TN, June 1983, pp. 121-144.

5 Swain, KM. and M.C. Remion. 1983. Direct control methods for the southern pine beetle. Agriculture Handbook 575. U.S. Department of Agriculture, Washington, DC.

6 Grzenda, A.P., H.P. Nicholson, J.I. Teasley and J.H. Patric. 1964. DDT residues in a mountain stream as influenced by treatment practices. J. Econ. Entomol. 57:615-618.

7 Douglass, J.E., D.R. Cochrane, G.W. Bailey, 1.1. Teasley and D.W. Hill, 1969. Low herbicide concentration found in streamflow after a grass cover is killed. Research Note SE-108. USDA Forest Service, Asheville, NC.

8, Norris, L.A. 1981. The movement, persistence, and fate of phenoxy herbicides and TCDD in the forest. Residue Rev, 80:65-135.

9. Anderson, H.W., M.D. Hoover and K.G. Reinhart. 1976. Forests and water: Effects of forest management on floods, sedimentation, and water supply, General Technical Report PSW-18. USDA Forest Service, Davis, CA.

IO. Crossley, D.A. and W.T. Swank, eds. 1987. Forest
Hydrology and Ecology of Coweeta. Springer-Verlag, New York, NY.

It. Hance, R.J., ed. 1987. Interactions Between Herbicides and the Soil. Academic, New York, NY.

12. Grover, R., ed. 1988. Environmental Chemistry of Herbicides, CRC, Boca Raton, FL.

13. Michael, J.L. and D.G. Neary. 1992. Herbicide dissipation studies in southern forest ecosystems. Environ. Toxicol. Chem. 12:405-410.

14. Mayer, F.L., Jr. and M.R. Ellersieck. 1986. Manual of acute toxicity: Interpretation and data base for 410 chemicals and 66 species of freshwater animals. U.S. Fish Wildl. Serv. Res. Publ.160.

15. Miller, J.H. and A.C. Bace. 1980. Streamwater contamination after aerial application of pelletized herbicide. Research Note SO-255. USDA Forest Service, New Orleans, LA.

16. Neary, D.G. 1983. Monitoring herbicide residues in springflow after an operational application of hexazinane. South.J. Appl. For. 7:217-223.

17. Neary, D.G., P.B. Bush and J.E. Douglass. 1983. Offsite movement of hexazinone in stormflow and baseflow from forest watersheds. Weed Sci. 31:543-551.

18. Bouchard, D.C., J.L. Lavy and E.R. Lawson. 1985. Mobility and persistence of hexazinone in a forested watershed. J. Environ. Qual. 14:229-233.

19. Neary, D.G. and J.L. Michael. 1989. Effect of sulfometuron methyl on groundwater and stream quality in coastal plain forest watersheds. Water Res. Bull. 25:617-623.

20. Bush, P.B., D.G. Neary and J.W. Taylor. 1988. Effect of triclopyramine and ester formulations on groundwater and surface runoff water quality in the coastal plain. Proc. South. Weed Sci. Soc. 39:262-270.

21. Neary, D.G., P.B. Bush, J.E. Douglass and R.L. Todd. 1985. Picloram movement in an Appalachian hardwood forest watershed. J. Environ. Qual. 14:585-592.

22. Bush, P.B., D.G. Neary, J.W. Taylor and W.L. Nutter. 1986. Effects of pesticide use in a pine seed orchard on pesticide levels in fish. Water Res. Bull. 22:817-827.

23. Neary, D.G., R.A. LaFayette, M.A. Callaham and P.B. Bush. 1986. Concentrations of $\mathrm{Cu}, \mathrm{Cr}, \mathrm{As}$, and PCP in sediments of a contaminated forest stream. Proceedings, Fourth Interagency Sedimentation Conference, Vol. 2, Las Vegas, NV, March 24-27, pp. 827 to $8-36$.

24. Neary, D.G., P.B. Bush, R.A. LaFayette, M.A. Callahan and J.W. Taylor. 1990. Copper, chromium, arsenic, and pentachlorophenol contamination of a southern Appalachian forest stream. In D.L. Weigmann, eds., Pesticides in Terrestrial and Aquatic Environments, Proceedings, National Pesticide Research Conference, Richmond! VA, May 11-12, 1989, Virginia Polytechnic Institute and State University, Blacksburg, VA, pp. 220.236 .

25. Michael, J.L., D.G. Neary and M.J.M. Wells. 1989. Picloram movement in soil solution and streamflow from a coastal plain forest. J. Environ. Qual. 18:89-95.

26. Bush, P.B., J.F. Dowd, A.G. Williams, D.G. Neary and J.W. Taylor. 1989. Pesticides in runoff from forested lands in the Southeast. In D.L. Weigmann, ed., Pesticides in Terrestrial and Aquatic Environments, Proceedings, Natural Research Conference, Rich- 
mond, VA, May I 1-12, Virginia Polytechnic Institute and State University, Blacksburg, VA, pp. 207-213.

27. Canter, L.W., R.C. Knox and D.M. Fairchild. 1987. MI.

Water Quality Protection. Lewis, Chelsea,

28. Neary, D.G. 1985. Fate of pesticides in Florida's forests: An overview of potential impacts on water quality. Soil Crop Sci.Soc, Fla. Proc, 44:18-23.

29. Bush, P.B., J.L. Michael, D.G. Neary and K.V. Miller. 1990. Effect of hexazinone on groundwater quality in the Coastal Plain. Proc. South. Weed Sci. Soc. 43:184-194.

30. Dowd, J.F., P.B. Bush, D.G. Neary, J.W. Taylor and Y.C. Berisford. 1992. Modeling pesticide movement in forested watersheds: Use of PRZM for evaluating pesticide options in loblolly pine stand management. Environ. Toxicol. Chem. 12:429-439.

31 Bush, P.B., W.L. Nutter, D.G. Neary and J.W. Taylor, 1989. Pesticide movement from southern pine seed orchards: Use of CREAMS model to facilitate evaluation of off-site pesticide movement. In D.G. Beasley, W.G. Knisel and A.P. Rice, eds. Proceedings, CREAMS/GLEAMS Symposium. Publication 4. University of Georgia, Athens, GA, pp. 209-220.

32. Crawford, L., J.F. Dowd, P.B. Bush, Y. Berisford, D.G. Neary and J.W. Taylor. 1991. Using GLEAMS to estimate insecticide movement from an Appalachian Mountain pine seed orchard. In D.L. Weigmann, ed., Pesticides in the Next Decade: The Challenges Ahend. Procestings. Third National Re: search Conference on Pesticides, Richmond, VA, Virginia Polytechnic Institute and State University, Blacksburg, VA, November 8-9,1990, pp. 707-724.

33,Bush, P.B., D.G. Neary, C.K. McMahon and H.L. Hendricks. 1986. Effect of burning on hexazinone residues in firewood. Proc. South. Weed Sci. Soc. 39:343-352.

34,Bush, P.B., D.G. Neary, C.K. McMahon and J.W. Taylor. 1987. Suitability of hardwoods treated with phenoxy and pyridine herbicides for use as firewood. Arch. Environ. Contam. Toxicol. 16:333-341.
35 Neary, D.G., P.B. Bush, C.K. McMahon, R.L. Cantrell and J.W. Taylor. 1988. Persistence of nine forest pesticides in the surface horizon of a Typic Quartzipsamment soil of the Ocala National Forest. Soil Crop Sci. Soc, F/a. Proc. 47:127-134.

36 Bush, P.B., J.W. Taylor, C.K. McMahon and D.G. Neary. 1987. Residues of lindane and chlorpyrifos in firewood and woodsmoke. J. Entomol. Sci. 22:131139.

37 USDA Forest Service. 1989. Final environmental impact statement, vegetation management in the Piedmont and Coastal Plain. Southern Region Management Bulletin R8-MB-23. Atlanta, GA.

38 Neary, D.G., P.B. Bush and M.A. Grant. 1986. Water quality of ephemeral forest streams after site preparation with the herbicide hexazinone. For. Ecol. Manage. 14:23-40.

39 Neary, D.G. and J.L. Michael. 1989. Appendix C: Effect of herbicides on soil .nroductivity and water quality. In Vegetation Management in the Piedmont and Coastal Plain, Vol. 2. Final Environmental Impact Statement, USDA Forest Service, Atlanta, GA.

40 Mayack, D.T., P.B. Bush, D.G. Neary and J.E. Douglass. 1982. Impact of hexazinone on invertebrates after application to forested watersheds. Arch. Environ. Contam. Toxicol. 11:209-217.

41 Wallace, J.B., J.R. Webster and T.F. Cuffney. 1982. Stream detritus dynamics: Regulation by invertebrate consumers. Oecologia 5X197-200.

42 Neary, D.G., J.E. Smith, B.F. Swindel and K.V. Miller. 1990. Effects of forestry herbicides on plant species diversity. Proc. South. Weed Sci. Soc. 43: $266-272$.

43. USDA Forest Service. 1989. Final environmental impact statement, vegetation management in the Appalachian Mountains. Southern Region Management Bulletin R8-MB-38. Atlanta, GA.

44 USDA Forest Service. 1990. Final environmental impact statement, vegetation management in the Ozark/ Ouachita mountains. Southern Region Management Bulletin R8-MB-45. Atlanta, GA. 